\title{
UPAYA MENINGKATKAN KINERJA DENGAN CARA MEMBERIKAN MOTIVASI KERJA DAN MENUMBUHKAN KOMITMEN ORGANISASIONAL PEGAWAI DINAS PERHUBUNGAN PROVINSI JAWA BARAT
}

\author{
R M Doni HA Wardhana \\ Universitas Pendidikan Indonesia \\ r.m@student.upi.edu \\ Eded Tarmedi \\ Universitas Pendidikan Indonesia \\ ededrarmedi@upi.edu \\ Sumiyati \\ Universitas Pendidikan Indonesia \\ sumiyati@upi.edu
}

\begin{abstract}
ABSTRAK
Tujuan - Tujuan dari makalah ini adalah untuk mengetahui pengaruh motivasi dan komitmen organisasi terhadap kinerja karyawan.

Desain/metodologi/pendekatan- Penelitian ini dilakukan pada jangka waktu kurang dari 1 tahun, maka desain penelitian adalah desain cross-sectional. Dan metode yang digunakan adalah survei explanatory, dan populasi 109 karyawan. Teknik analisis yang digunakan adalah alat analisis jalur di olah menggunakan SPSS 16.0. kuesioner digunakan sebagai instrumen penelitian untuk mengumpulkan data dari responden.

Temuan - kinerja karyawan dipengaruhi oleh motivasi kerja dan komitmen organisasi secara signifikan dan positif.

Orisinalitas/nilai - Motivasi dan komitmen organisasi digunakan sebagai cara untuk meningkatkan kinerja karyawan. Penelitian ini bertujuan untuk mendeskripsikan motivasi, komitmen organisasi terhadap kinerja karyawan. motivasi pengaruh dan komitmen organisasi kepada karyawan lembaga transportasi kinerja di Jawa Barat. Objek yang menjadi unit analisis dalam penelitian ini adalah karyawan dari departemen transportasi dari Jawa Barat. Independet variable $\left(\mathrm{X}_{1}\right)$ dalam penelitian ini motivasi adalah dan $\left(\mathrm{X}_{2}\right)$ komitmen organisasi, serta variabel dependen (Y) adalah kinerja para karyawan.
\end{abstract}

Kata kunci: Motivasi, komitmen organisasi, Kinerja Karyawan, Manajemen Sumber Daya Manusia Jenis Artikel: Research Paper

\section{PENDAHULUAN}

Kinerja bisa mempengaruhi berlangsungnya kegiatan suatu organisasi perusahaan, semakin baik kinerja yang ditunjukkan oleh para karyawan akan sangat membantu dalam perkembangan organisasi atau perusahaan tersebut. Kinerja pegawai merupakan salah satu faktor yang memegang peranan penting dalam mencapai tujuan perusahaan maupun tujuan individu. Perusahaan akan sulit mencapai tujuannya jika para pegawai di perusahaan tersebut tidak memiliki kinerja yang baik. Menurut (Veithzal, 2010) "Kinerja merupakan perilaku yang nyata yang ditampilkan setiap orang sebagai prestasi kerja yang dihasilkan oleh karyawan sesuai dengan perannya dalam perusahaan." Kinerja merupakan hasil kerja yang telah dicapai seseorang sesuai dengan tugas dan perannya sesuai dengan tujuan organisasi yang dihubungkan dengan standar kinerja tertentu dari perusahaan dimana individu tersebut bekerja. Oleh sebab itu keberhasilan dan kinerja seseorang dalam suatu bidang pekerjaan banyak ditentukan oleh motivasi dan komitmennya terhadap bidang yang ditekuni.

Untuk menghadapi persaingan yang semakin ketat, perusahaan ini dihadapkan pada kondisi pentingnya untuk meningkatkan kinerja pegawai. Kinerja pegawai yang baik akan menghasilkan kinerja perusahaan yang baik pula sehingga memudahkan perusahaan untuk mencapai tujuannya. Kinerja pegawai dipengaruhi oleh berbagai faktor, diantaranya motivasi, disiplin, kepemimpinan, suasana kerja, kompetensi, dan lain sebagainya (Mulyadi, 2010)

Usaha untuk mencapai tujuan perusahaan diperlukan adanya pegawai yang penuh kesadaran, kesetiaan, ketaatan, disiplin dan bertanggung jawab atas segala pekerjaan yang diberikan dan telah dikerjakan. Setiap perusahaan tentunya sangat mengharapkan memiliki pegawai yang memiliki kinerja yang baik. Semakin banyak pengawai yang mempunyai kinerja, maka produktivitas perusahaan secara keseluruhan akan 
meningkat sehingga perusahaan akan lebih mudah dalam mencapai tujuan. Untuk dapat mengukur sejauh mana kinerja pegawai dapat memberikan kemampuannya yang optimal dapat kita lihat dari beberapa indikator, misalnya kedisiplinan, kesetiaan dan tanggung jawab.

Tingkat kesuksesan suatu perusahaan dapat diukur berdasarkan produktivitas perusahaan dari tiap individu yang bekerja di dalamnya, dimana produktivitas individu merupakan ukuran dari produktivitas perusahaan secara keseluruhan. Produktivitas individu merupakan perbandingan dari efektivitas keluaran (pencapaian unjuk kerja yang maksimal) dengan efisiensi adalah satu masukan (tenaga kerja) yang mencakup kuantitas, kualitas dalam satuan waktu tertentum(Mulyadi, 2010)

Motivasi merupakan kondisi atau energi yang menggerakkan diri karyawan yang terarah atau tertuju untuk mencapai tujuan perusahaan (Syamsul Hadi Senen, 2008)

Fenomena yang dialami perusahaan harus segera ditanggulangi sebab akan menghambat tujuan perusahaan yang mungkin bisa mengarah pada kehancuran perusahaan tersebut. Oleh sebab itu, perusahaan harus mencari solusi yang tepat untuk meningkatkan kinerja karyawannya yaitu dengan cara memberikan motivasi dan meningkatkan kedisiplinan para karyawannya (Mulyadi, 2010).

Salah satu faktor yang mempengaruhi kinerja pegawai adalah motivasi. Motivasi kerja merupakan suatu hal yang sangat dibutuhkan oleh seorang pegawai, semakin tinggi motivasi kerja pegawai maka akan meningkatnya kinerja yang akan diberikan oleh pegawai tersebut kepada instansi tempat dimana mereka bekerja. Motivasi mempunyai kekuatan kecenderungan seseorang/individu untuk melibatkan diri dalam kegiatan yang mengarah kepada sasaran dalam pekerjaan sebagai kepuasan, tetapi lebih lanjut merupakan perasaan senang atau rela bekerja untuk mencapai tujuan pekerjaan.

Kunci keberhasilan suatu perusahaan bergantung pada kualitas sumber daya manusia yang dimilikinya. Sumber daya manusialah yang menentukan keberlangsungan perusahaan. Keberhasilan pencapaian akan didapat apabila SDM didalam perusahaan memiliki kinerja yang tinggi (Elis Lisnawati, 2014)

Setiap organisasi tentu ingin mencapai tujuan, untuk mencapai tujuan tersebut, peranan manusia yang terlibat didalamnya sangat penting. Untuk menggerakkan manusia agar sesuai dengan yang dikehendaki organisasi, maka haruslah dipahami motivasi manusia yang bekerja di dalam organisasi tersebut. Motivasi inilah yang menentukan perilaku orang-orang untuk bekerja, atau dengan kata lain perilaku merupakan cerminan yang paling sederhana dari motivasi (Sutrisno (2010:109) dalam (Mahmud, 2010).

Pernyataan tentang adanya suatu hubungan antara motivasi kerja dan kinerja dikemukakan oleh McClelland (dalam buku (Mangkunegara, 2010) menyimpulkan bahwa ada hubungan positif antara motivasi kerja dengan pencapaian prestasi kerja atau kinerja; "Dimana jika seorang manajer atau pimpinan yang mempunyai motivasi kerja tinggi cenderung memiliki prestasi kerja atau kinerja yang tinggi, dan sebaliknya mereka yang prestasi kerjanya rendah dimungkinkan karena motivasi kerjanya rendah."

Menurut (Simamora, 2011) menyatakan bahwa terdapat hubungan antara motivasi kerja terhadap kinerja. Faktor yang mempengaruhi kinerja diantaranya yaitu motivasi kerja. Hal ini dilihat dari pernyataan Henry Simamora mengenai faktor-faktor yang mempengaruhi kinerja, diantaranya faktor psikologis, dalam faktor ini terdapat variabel motivasi kerja terhadap pekerjaannya sendiri. Berdasarkan dari pernyataan diatas bahwa terdapat hubungan antara motivasi kerja terhadap kinerja.

Peranan sumber daya manusia sebagai pelaku utama, maka seorang manejer harus mengatur karyawannya dengan baik karena karyawan merupakan input dari produktivitas dalam perusahaan sehingga kinerja karyawan harus dipelihara dan ditingkatkan seoptimal mungkin (Mulyadi, 2010)

Untuk dapat mencapai kinerja yang diharapkan Dinas Perhubungan harus memiliki keunggulan kompetitif yang hanya akan diperoleh dari sumber daya manusia yang produktif, inovatif, kreatif selalu bersemangat dan loyal. Sumber daya manusia organisasi atau pegawai yang memenuhi kriteria seperti itu hanya akan dimiliki melalui peningkatan komitmen pegawai terhadap organisasi. Komitmen organisasi seorang pegawai dengan pegawai lain memiliki tingkat yang berbeda. Membina dan mengembangkan sumber daya manusia serta menjaga komitmen pegawai merupakan kewajiban organisasi.

Pengalokasian sumber daya manusia tidak bisa dipandang mudah. Pegawai yang dimiliki organisasi harus memiliki rasa kepemilikan terhadap organisasi tempatnya bekerja. Selain rasa memiliki, sikap dan loyalitas pegawai terhadap organisasi berpengaruh terhadap dedikasi pegawai dalam melaksanakan tugas dan tanggung jawabnya. dedikasi tinggi serta loyalitas yang kuat dari pegawai akan menimbulkan komitmen pegawai terhadap organisasi.

\section{KAJIAN PUSTAKA}

Kinerja karyawan merupakan suatu hal yang sangat penting dalam upaya perusahaan untuk 
mencapai tujuannya serta menjadi salah satu faktor utama keberhasilan suatu perusahaan. Pada dasarnya kinerja seorang karyawan merupakan hal yang bersifat individual karena setiap karyawan mempunyai tingkat kemampuan yang berbeda-beda dalam mengerjakan pekerjaannya. Segala upaya manajemen di dalam perusahaan, khususnya Manajemen Sumber Daya Manusia (MSDM) adalah untuk mempertinggi, baik kinerja individu maupun organisasional. (Rivai, 2009) mengemukakan bahwa "Kinerja merupakan perilaku nyata yang ditampilkan setiap orang sebagai prestasi kerja yang dihasilkan oleh karyawan sesuai dengan perannya dalam perusahaan." Menurut (Robbins, P. Stephen \& Judge, 2010), kinerja adalah hasil akhir dari sebuah aktifitas. Pengertian tersebut bermakna bahwa, kinerja adalah hasil akhir dari suatu kegiatan. Menurut (Sumarno, 2005) Kerjasama diantara sesama pekerja mendefinisikan kinerja karyawan adalah apa yang dilakukan atau tidak dilakukan karyawan dalam memberikan kontribusi kepada organsasi yang meliputi kuantitas output, kualitas output, jangka waktu output, kehadiran di tempat kerja, dan sikap kooperatif.

Sedangkan (Hasibuan, 2011) menyatakan bahwa prestasi kerja adalah suatu hasil kerja yang dicapai seseorang dalam melaksanakan tugastugas yang dibebankan kepadanya yang didasarkan kecakapan, pengalaman, kesungguhan, serta waktu. Menurut (Hariandja, 2002) menyatakan bahwa unjuk kerja merupakan hasil kerja yang dihasilkan oleh pegawai atau prilaku nyata yang ditampilkan sesuai dengan perannya dalam organisasi. Charity Tino Firei dalam International Journal yang berjudul The Unique Factors Affecting Employee Performance In Non Profit Organisations (2011:12) "Performance is the accomplishment of a given task measured against pre-set standards of acuracy, completeness, cost and speed." Kinerja adalah prestasi yang diberikan atas ukuran tugas terhadap ukuran ketepatan, kelengkapan, ongkos dan kecepatan

Berdasarkan definisi kinerja karyawan dari para ahli diatas, dapat disimpulkan bahwa kinerja merupakan kualitas dan kuantitas dari suatu hasil kerja (output) individu maupun kelompok dalam suatu aktivitas tertentu yang diakibatkan oleh kemampuan alami atau kemampuan yang diperoleh dari proses belajar serta keinginan untuk berprestasi.

Motivasi merupakan suatu permasalahan yang selalu ada dalam suatu organisasi, baik itu organisasi nirlaba atau bukan. Motivasi mempunyai peranan penting dalam pencapaian tujuan perusahaan, dapat dikatakan kemajuan suatu organisasi berawal dari motivasi yang dimiliki oleh para karyawannya. Banyak perusahaan yang selalu me-refresh motivasi dalam bekerja agar selalu dapat membawa kemajuan, meskipun untuk itu perusahaan terkadang harus mengeluarkan biaya yang tidak sedikit demi pencapaian tujuan perusahaan lewat motivasi itu sendiri (Hasibuan, 2011). Pencapaian tujuan suatu organisasi sangat bergantung kepada kemauan para pegawai untuk bekerja lebih giat. Agar pegawai bekerja lebih giat maka mereka perlu diberi motivasi dengan berbagai cara. Pada umumnya tingkah laku manusia dilakukan secara sadar, artinya selalu didorong oleh keinginan untuk mencapai tujuan tertentu. Disinilah letaknya peran penting dari motivasi.

Berdasarkan hasil penelitian diketahui bahwa indikator-indikator yang terdapat pada motivasi kerja termasuk ke dalam dua kategori, yaitu sedang dan tinggi. Indikator yang termasuk ke dalam kategori sedang ialah kebebasan menyampaikan pendapat, sedangkan indikator yang termasuk ke dalam kategori tinggi antara lain semangat kerja, loyalitas terhadap pimpinan, perasaan bangga terhadap hasil yang dicapai, upah atau gaji, hadiah atau bonus, tunjangan, suasana kerja, pengembangan potensi, dan kemampuan (Purnama, 2008).

Pengalokasian sumber daya manusia tidak bisa dipandang mudah. Pegawai yang dimiliki organisasi harus memiliki rasa kepemilikan terhadap organisasi tempatnya bekerja. Selain rasa memiliki, sikap dan loyalitas pegawai terhadap organisasi berpengaruh terhadap dedikasi pegawai dalam melaksanakan tugas dan tanggung jawabnya. dedikasi tinggi serta loyalitas yang kuat dari pegawai akan menimbulkan komitmen pegawai terhadap organisasi. terdapat hubungan yang erat antara kinerja perorangan (individual performance) dengan kinerja lembaga (institutional performance). Dengan perkataan lain kinerja seorang karyawan (individual performance) baik maka kemungkinan besar kinerja perusahaan (corporate performance) juga baik. Kinerja pegawai yang baik didukung dengan memiliki kemampuan dan pengetahuan tentang karakteristik pekerjaannya sehingga akan membantu karaywan di dalam menyelesaikan pekerjaannya (Syamsul Hadi Senen, 2015)

Menurut (Oei, 2010), komitmen organisasi (organizational commitment) adalah kekuatan relatif pengenalan pada keterlibatan dari dalam diri seorang individu dalam organisasi tertentu. (Robbins, P. Stephen \& Judge, 2010) mendefinisikan komitmen organisasi sebagai suatu keadaan di mana seorang pegawai memihak pada suatu organisasi tertentu dan tujuantujuannya, serta berniat memelihara keanggotaan dalam organisasi itu. Porter et.al (1974) dalam Moynihan, et.al (2002) mengatakan 
"organizational commitment as an individual's identification and involvement with an organization." Pengertian komitmen organisasional menurut (Yunianto, 2009) adalah identifikasi rasa, keterlibatan loyalitas yang ditampakkan oleh pekerja terhadap organisasinya atau unit Organisasi. Menurut (Sopiah, 2010) komitmen organisasi adalah suatu ikatan psikologis karyawan pada organisasi yang ditandai dengan kepercayaan dan penerimaan yang kuat atas tujuan dan nilai-nilai organisasi, kemauan untuk mengusahakan tercapainya kepentingan organisasi, keinginan yang kuat untuk mempertahankan kedudukan sebagai anggota organisasi.

Keberadaan manusia sebagai sumber daya manusia adalah sangat penting dalam organisasi karena sumber daya manusia menunjang organsiasi melalui karya, bakat, kreativitas, dorongan dan peran nyata seperti yang dapat dilihat dalam setiap organisasi. Tanpa adanya unsur manusia dalam sebuah organisasi di mana keberhasilan dalam mencapai tujuan organisasi sangat ditentukan oleh kinerja karyawannya (Syamsul Hadi Senen, 2015).

Gambar 1 Paradigma Penelitian

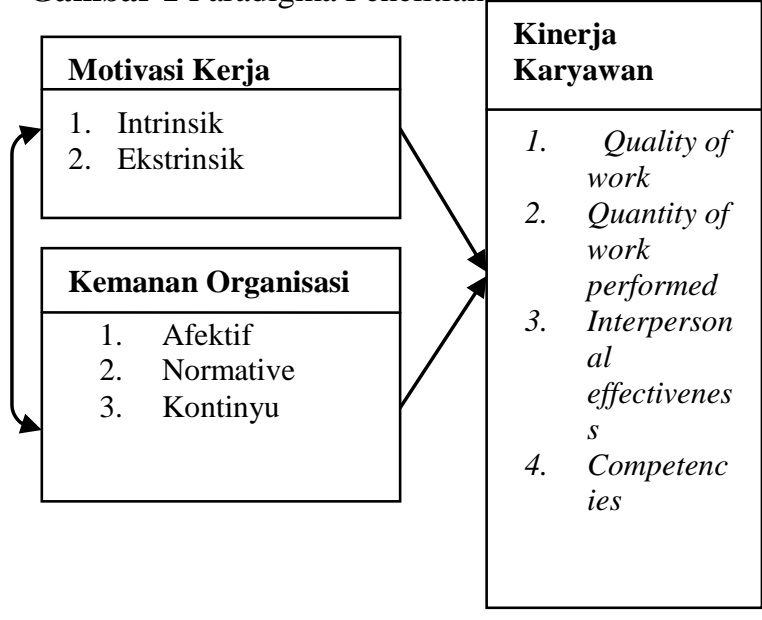

\section{METODE PENELITIAN}

Objek penelitian dalam penelitian ini adalah motivasi kerja, komitmen organisasional dan kinerja karyawan. Adapun yang menjadi variabel bebas dalam penelitian ini adalah motivasi kerja, komitmen organisasional dan variabel terikatnya adalah kinerja karywan. Populasi dalam penelitian ini sebanyak 109 responden, Teknik pengumpulan data dilakukan dengan menyebar kuisioner.

Penelitian ini dilakukan pada kurung waktu kurang dari satu tahun, maka metode penelitian yang digunakan adalah cross sectional method. Jenis penelitan yang digunakan adalah penelitian deskriftif dan verifikatif. Dengan demikian, maka dalam penelitian ini akan dilakukan pengujian mengenai seberapa besar pengaruh motivasi kerja dan komitmen organisasional terhadap kinerja karyawan. Berdasarkan jenis penelitian tersebut, maka metode yang digunakan dalam penelitian ini adalah explanatory survey yang bertujuan untuk menguji hipotesis antara variabel yang satu dengan variabel yang lain.

\section{HASIL PENELITIAN DAN PEMBAHASAN}

Pengujian ini dilakukan untuk mengukur seberapa besar motivasi kerja dan komitmen organisasional terhadap kinerja pegawai Dinas Perhubungan Provinsi Jawa Barat. Hipotesis yang diuji dalam penelitian ini terdiri dari motivasi kerja dan komitmen organisasional terhadap kinerja karyawan. Pengujian parsial dapat dilakukan setelah dipastikan adanya pengaruh yang signifikan antara pengaruh motivasi kerja dan komitmen organisasional terhadap kinerja karyawan pada uji simultan. Hasil korelasi antara motivasi kerja, komitmen organisasional terhadap kinerja pegawai. Hipotesis ini diuji secara simultan maupun parsial dengan menggunakan SPSS 22.0 for windows. Hasil pengujian hipotesis secara keseluruhan (simultan) dapat dilihat berdasarkan tabel anova dengan nilai $\mathrm{F}$ hitung sebesar 99,250 dan F tabel 3,082, hasil tersebut menunjukkan bahwa $F_{\text {hitung }}(99,250)>F_{\text {tabel }}$ $(3,082)$ maka dapat diambil keputusan bahwa hipotesis nol $\left(\mathrm{H}_{0}\right)$ ditolak dan $\mathrm{H}_{\mathrm{i}}$ diterima, sehingga dapat dikatakan bahwa terdapat hubungan linear antara motivasi kerja dan komitmen organisasi terhadap kinerja pegawai. Hasil tersebut juga menunjukkan bahwa model regresi yang digunakan sudah layak dan benar. Uji angka probabilitas (Sig) menunjukkan hasil bahwa nilai tingkat probabilitas $(\mathrm{Sig})=0,000$, karena nilai Sig $(0,000) \leq 0,05$ maka keputusannya adalah $\mathrm{H}_{0}$ ditolak dan $\mathrm{H}_{\mathrm{i}}$ diterima, hal tersebut memberikan arti bahwa secara simultan (keseluruhan) terdapat pengaruh antara motivasi kerja dankomitmen organisasi terhadap kinerja karyawan.

Hasil pengujian secara simultan menunjukkan hasil yang signifikan, untuk mengetahui variabel bebas yang berpengaruh nyata terhadap variabel terikat maka dapat dilanjutkan dengan pengujian secara parsial. Matriks korelasi antara motivasi kerja dan komitmen organisasi terhadap kinerja karyawan dapat dilihat berdasarkan tabel menunjukan hubungan setiap variabel motivasi kerja, komitmen organisasional dan kinerja karyawan. Berdasarkan hasil matriks korelasi antara motivasi kerja, komitmen organisasional dan kinerja pegawai, diperoleh hasil korelasi secara berurutan yaitu motivasi kerja sebesar $(0,807)$, dan komitmen organisasional sebesar $(0,511)$. Variabel motivasi kerja memiliki korelasi 
terbesar yaitu sebesar 0,807, hal ini dapat dikatakan bahwa motivasi kerja karyawan pada perusahaan ini tinggi dan sangat berkaitan dengan kinerja karyawan,

Sedangkan yang memiliki korelasi terendah terdapat pada variabel komitmen organisasional yaitu sebesar 0,511. Hal ini dikarenakan karyawan belum mencapai target kerja yang telah di tentukan sebelumny secara maksimal sehingga belum dapat di apresiasi secara penuh oleh dinas terkait. Menjelaskan secara lengkap mengenai pengaruh masing-masing variabel motivasi kerja, dan komitmen organisasional terhadap kinerja karyawan.

Berdasarkan hasil perhitungan diatas, maka dapat digambarkan diagram jalur dari hipotesis pada penelitian sebagai berikut:

Gambar 2 Diagram Jalur Pengujian Hibotesis

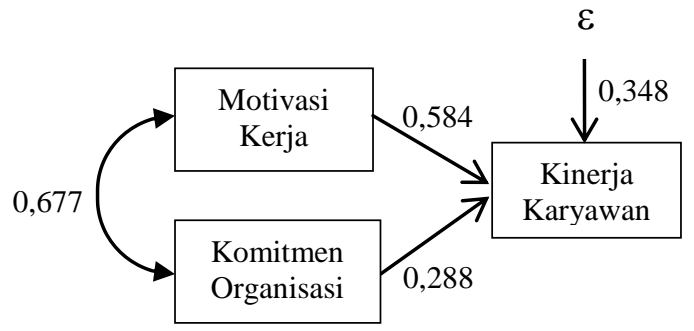

Pengaruh langsung antara motivasi kerja dan komitmen organisasional terhadap kinerja karyawan yang paling besar pengaruhnya secara parsial yaitu motivasi kerja terhadap kinerja karyawan sebesar $(0,455: 0,652) \times 100 \%=69,7 \%$ . Sedangkan pengaruh komitmen organisasional terhadap kinerja karyawan sebesar $(0,197: 0,652)$ $\mathrm{x} 100 \%=30,3 \%$. Dapat diketahui bahwa total koefisien jalur dari motivasi kerja dan komitmen organisasional terhadap kinerja karyawan adalah sebesar 0,652

Hasil tersebut menunjukan bahwa motivasi kerja $\left(\mathrm{X}_{1}\right)$ dan komitmen organisasional $\left(\mathrm{X}_{2}\right)$ secara simultan mempengaruhi terhadap terhadap kinerja karyawan (Y) pada karyawan dinas Perhubungan Provinsi Jawa Barat yaitu sebesar $65,2 \%$. Sedangkan pengaruh variabel lain yang tidak diteliti untuk karyawan dinas perhubungan provinsi Jawa Barat adalah sebesar 0,348 x $100 \%$ $=34,8 \%$.

Penelitian ini mencoba mengungkapkan motivasi, komitmen organisasi dan kinerja pegawai pada Dinas Perhubungan Provinsi Jawa Barat. Selanjutnya menerangkan variabel motivasi dan komitmen organisasi berpengaruh terhadap kinerja pegawai pada Dinas Perhubungan Provinsi Jawa Barat. Hasil penelitian ini memberikan gambaran bahwa kinerja pegawai dipengaruhi oleh motivasi dan komitmen organisasi, dari hasil penelitian ini diharapkan akan menyumbangkan data untuk melakukan perbaikan selanjutnya khususnya pada Dinas Perhubungan Provinsi Jawa Barat. Lebih jauhnya untuk peneliti berikutnya terbukti bahwa kinerja pegawai dipengaruhi oleh motivasi dan komitmen organisasi.

Total pengaruh secara keseluruhan adalah $65,2 \%$, efek faktor lain yang tidak diteliti terhadap kinerja pegawai ditunjukkan oleh nilai $\square \mathrm{y} \square=0,348$ sebesar $34,8 \%$ merupakan faktor lain yang tidak diteliti dalam penelitian ini yang mempengaruhi kinerja pegawai. Hasil penelitian ini menguatkan bahwa jika variabel motivasi dan komitmen organisasi secara bersama-sama dilakukan dengan baik, maka akan berpengaruh terhadap peningkatan kinerja pegawai. Jika faktor-faktor lain yang mempengaruhi kinerja pegawai ditambah kemungkinan kontribusinya akan lebih sempurna. Sejalan dengan pendapat (Martoyo, 2009): "Sebetulnya memang banyak faktor yang dapat mempengaruhi kinerja karyawan, antara lain: motivasi, kepuasan kerja, tingkat stres, kondisi fisik pekerjaan, rekrutmen, analisis jabatan, deskripsi jabatan, sistem kompensasi, aspek-aspek ekonomis, aspek-aspek teknis, perilaku-perilaku lainnya."

Berdasarkan hasil pengolahan data melalui analisis jalur, variabel motivasi mempunyai pengaruh sebesar $19,7 \%$ terhadap kinerja pegawai. Seperti yang dikemukakan oleh (Mangkunegara, 2011) bahwa ada hubungan positif antara motivasi kerja dengan pencapaian prestasi kerja atau kinerja; "Dimana jika seorang manajer atau pimpinan yang mempunyai motivasi kerja tinggi cenderung memiliki prestasi kerja atau kinerja yang tinggi, dan sebaliknya mereka yang prestasi kerjanya rendah dimungkinkan karena motivasi kerjanya rendah. Hal ini diperkuat kembali oleh (Simamora, 2011) bahwa terdapat hubungan antara motivasi kerja terhadap kinerja. Faktor yang mempengaruhi kinerja diantaranya yaitu motivasi kerja. Hal ini dilihat dari pernyataan Henry Simamora mengenai faktor-faktor yang mempengaruhi kinerja, diantaranya faktor psikologis, dalam faktor ini terdapat variabel motivasi kerja terhadap pekerjaannya sendiri. Berdasarkan dari pernyataan diatas bahwa terdapat hubungan antara motivasi kerja terhadap kinerja.

Berdasarkan hasil penglolahan data melalui analisis jalur, diperoleh variabel komitmen organisasi mempunyai pengaruh sebesar $45,5 \%$ terhadap kinerja pegawai. Individu yang memiliki komitmen organisasional rendah cenderung untuk melakukan cara yang dapat mengganggu kinerja organisasi seperti turnover yang tinggi, kelambanan dalam bekerja, keluhan dan bahkan mogok kerja. (Rivai, 2009) menyatakan bahwa komitmen organisasional berpengaruh signifikan terhadap kinerja. Semakin tinggi komitmen 
organisasional dari karyawan maka akan semakin meningkat kinerja individual karyawan. Hal ini diperkuat oleh (Elya Wati, Lismawati, 2010) bahwa "Komitmen yang tepat akan memberikan motivasi yang tinggi dan memberikan dampak yang positif terhadap kinerja suatu pekerjaan. Jika auditor merasa jiwanya terikat dengan nilai-nilai organisasional yang ada maka dia akan merasa senang dalam bekerja, sehingga kinerjanya dapat meningkat. Hal ini berarti bahwa semakin tinggi komitmen seorang auditor pemerintah terhadap organisasi, maka kinerja auditor pemerintah akan semakin baik."

\section{KESIMPULAN \& REKOMENDASI}

Berdasarkan uraian teori dan hasil penelitian yang telah dilakukan dengan menggunakan analisis deskriptif dan verifikatif serta uji path atau analisis jalur antara motivasi kerja dan komitmen organisasional terhadap kinerja karyawan Dinas Perhubungan Provinsi Jawa Barat, dapat ditarik kesimpulan bahwa secara simultan (keseluruhan) terdapat pengaruh yang positif antara pengaruh motivasi kerja yang terdiri dari intrinsik dan ekstrinsik dan komitmen organisasional yang terdiri dari afektif, normatif, kontinyu terhadap kinerja karyawan yang terdiri dari dimensi quality of work, quantity of work, interpersonal effectivness, dan compenticies. Menunjukkan bahwa motivasi kerja dan komitmen organisasional berpengaruh secara positif terhadap kinerja karyawan.

\section{DAFTAR PUSTAKA}

Elis Lisnawati. (2014). Pengaruh Organisasi Pembelajarandan Kompetensi Kerja Terhadap Kinerja Karyawan PT.Technomed Asia Di Padalarang, 1-21.

Elya Wati, Lismawati, N. A. (2010). Pengaruh Independensi, Komitmen Organisasi, Dan Pemahaman Good Governance Terhadap Kinerja Auditor Pemerintah. Purwokerto.

Hariandja, M. T. . (2002). manajemen sumber daya manusia. Jakarta: Grasindo.

Hasibuan, M. (2011). Manajemen Sumber Daya Manusia. Jakarta: Bumi Aksara.

Mahmud, S. dan. (2010). Membangun Kinerja Karyawan Melalui Motivasi Kerja, Kepuasan Kerja Dan Komitmen Organisasi Pada PT. Astra International Di Semarang. Jurusan Manajemen Fakultas Ekonomi dan Bisnis Universitas Dian Nuswantoro.

Mangkunegara, A. P. (2010). Manajemen Sumber Daya Manusia Perusahaan. Bandung: PT Remaja Rosda Karya.

Mangkunegara, A. P. (2011). Manajemen Sumber
Daya Manusia. Bandung: PT Remaja Rosda Karya.

Martoyo, S. (2009). Sumber Daya Manusia. Yogyakarta.

Mulyadi, H. (2010a). Pengaruh Motivasi Dan Disiplin Kerja Terhadap Kinerja Karyawan Pada Departmen Weaving.

Mulyadi, H. (2010b). Pengaruh Motivasi Dan Kompetensi KerjaTerhadap Produktivitas Kerja Karyawan Pada PT . Galamedia Bandung Perkasa, 97-111.

Oei, I. (2010). Manajemen Sumber Daya Manusia. Jakarta: PT. Gramedia.

Purnama, R. (2008). Pengaruh Motivasi Kerja Terhadap Produktivitas Kerja Karyawan Pada Bagian Produksi CV . Epsilon Bandung, 58-72.

Rivai, V. \& E. J. (2009. (2009). Manajemen Sumber Daya Manusia untuk Perusahaan. Jakarta: PT Raja Grafindo.

Robbins, P. Stephen \& Judge, T. A. (2010). Perilaku Organisasi. Jakarta: Salemba Empat.

Simamora, H. (2011). Manajemen Sumber Daya Manusia. Yogyakarta.

Sopiah. (2010). Perilaku Organisasi. Yogyakarta: andi.

Sumarno, J. (2005). Pengaruh Komitmen Organisasi Terhadap Hubungan Antara Partisipasi Anggaran dan Kinerja Manajerial (Studi Empiris Pada Kantor Cabang Perbankan Indonesia Di Jakarta). Solo: Sna Viii Solo.

Syamsul Hadi Senen. (2008). Pengaruh Motivasi Kerja dan Kemampuan Kerja KaryawanTerhadap Produktivitas Kerja Karyawan Pada PT. Saflindo Permata, 7(September), 1-15.

Syamsul Hadi Senen, M. (2015). Analisis Job Performance Pegawai Honorer Administrasi Dengan Kompetensi dan Job Characteristics Dalam Mendukung Universitas Pendidikan Indonesia Mencapai Leading And Outstanding ( Job Performance Analysis Temporary Employee Administrative with Competence , 120-137.

Veithzal, R. (2010). Manajemen Sumber Daya Manusia untuk Perusahaan. Jakarta: Raja Grafindo Persada.

Yunianto, L. P. D. A. (2009). Motivasi Terhadap Kinerja Dengan Komitmen Organisasional Sebagai Mediasi. 